Thu Feb 13 18:26:29 2020

Citations:

Bluebook 20th ed.

David L. Callies, A Federal Requiem for Public Use: And a Blueprint for State Action, 57 Planning \& Envtl. L. 10 (2005).

ALWD 6th ed.

David L. Callies, A Federal Requiem for Public Use: And a Blueprint for State Action, 57 Planning \& Envtl. L. 10 (2005).

APA 6th ed.

Callies, D. L. (2005). federal requiem for public use: And blueprint for state action. Planning \& Environmental Law, 57(9), 10-11.

Chicago 7th ed.

David L. Callies, "A Federal Requiem for Public Use: And a Blueprint for State

Action," Planning \& Environmental Law 57, no. 9 (September 2005): 10-11

McGill Guide 9th ed.

David L Callies, "A Federal Requiem for Public Use: And a Blueprint for State Action" (2005) 57:9 Planning \& Environmental L 10.

MLA 8th ed.

Callies, David L. "A Federal Requiem for Public Use: And a Blueprint for State

Action." Planning \& Environmental Law, vol. 57, no. 9, September 2005, p. 10-11.

HeinOnline.

OSCOLA 4th ed.

David L Callies, 'A Federal Requiem for Public Use: And a Blueprint for State Action' (2005) 57 Planning \& Envtl L 10

Provided by:

William S. Richardson School of Law

-- Your use of this HeinOnline PDF indicates your acceptance of HeinOnline's Terms and Conditions of the license agreement available at https://heinonline.org/HOL/License

-- The search text of this PDF is generated from uncorrected OCR text.

-- To obtain permission to use this article beyond the scope of your license, please use: Copyright Information 

domain.

poses. It will also provide a marina, a public walkway along the Thames River, a site for the Coast Guard museum, and public parking facilities for the museum and a nearby state park. So if we ban eminent domain for projects designed solely for economic development, this would quite likely not cover the New London

Redevelopment project and any number of similar projects.

The prohibitory approach, even if we could solve the definitional dilemmas, also requires that there be someone to enforce the ban. Do the sponsors intend to create a new federal cause of action permitting eminent domain opponents to take local officials to federal court for a ruling on whether their projects are permissible? Do we really want federal judges deciding whether local development projects should be allowed to go forward or not?

And where are the lawyers going to come from to represent the landowners who object to their property being taken for economic development? Property owners currently rely on lawyers who work for a percentage of any additional compensation they obtain for the owners. These lawyers have a strong incentive to argue that their clients are entitled to more money, since that will automatically increase their fees. But their incentives to argue that the taking is prohibited are obviously more problematic; if they push too hard and the argument actually prevails, there may be no money to pay their fees.

A better reform idea would be to require more complete compensation for persons whose property is taken by eminent domain. The constitutional standard requires fair market value, no more and no less. Congress modified this when it passed the Uniform Relocation Act in 1970 , which requires some additional compensation for moving expenses and loss of personal property. Congress could modify the Relocation Act again, in order to nudge the compensation formula further in the direction of providing truly "just" compensation.

For example, Congress could require that when occupied homes, businesses or farms are taken, the owner is entitled to a percentage bonus above fair market value, equal to one percentage point for each year the owner has continuously occupied the property. This would provide significant additional compensation for the Susette Kelos and Wilhelmina Derys who are removed from homes they have lived in for much of their lives.

Alternatively, Congress could require that when a condemnation produces a gain in the underlying land values due to the assembly of multiple parcels, some part of this assembly gain has to be shared with the people whose property is taken. Under current law, all of the assembly gain goes to the condemning authority, or the entity to which the property is transferred after the condemnation.

Either one of these adjustments in the measure of just compensation-or others that might be advanced if Congress held serious hearings on the matter-would do more to protect homeowners against eminent domain than declaring a federal prohibition on takings for economic development. Adjustments in compensation would protect all property owners-those whose property is taken for highways and public housing projects, as well as those whose property is taken for economic development projects. Such a requirement would be vigorously enforced by the attorneys who represent property owners in condemnation proceedings.

Providing additional compensation in cases of greatest concern would discourage local governments from using eminent domain in these cases, without prohibiting its use altogether. Perhaps most importantly, assuring a more "just" measure of compensation would leave the ultimate decision about when to exercise this power in the hands of local elected officials, where it has long been lodged, and where it belongs.

\title{
A Federal Requiem for Public Use: and a Blueprint for State Action
}

\author{
By David L. Callies, FAICP
}

\begin{abstract}
A bare majority of the Kelo Court upheld the exercise of eminent domain for the purpose of economic revitalization. Heavily relying on its previous decisions in Berman and Midkiff, the Court stated it was too late in the game to revisit its present expansive view of public use. There is no difference in modern eminent domain practice between public use and public purpose,
\end{abstract}

at least in federal court. Indeed, the Court, by a narrow $5-4$ vote, specifically equated public use and public purpose before holding that condemning land for economic revitalization was simply another small step along the continuum of permitting public benefits to be sufficient indicia of meeting public use/public purpose requirements. As the Court also noted, it is now up to the states to decide whether or not to increase the burden on the government's exercise of compulsory purchase powers. The federal bar is presently set so low as to be little more than a speed bump.

The Court bluntly rejected any suggestion that it formulate a more rigorous test. To require government to show that public benefits would actually accrue with reasonable certainty or that the implementation 
There is no doubt that state and local governments will do

of a development plan would actually occur would take the Court into factual inquiries already rejected earlier in the term when the Court rejected the "substantially advances a legitimate state interest" test for regulatory takings in Lingle. In a nod to federalism and states' rights, the Court closed by leaving to the states any remedy for such hardships posed by the condemnations in New London.

Only Justice Kennedy's concurrence suggests some small role remains for federal courts in determining that a particular exercise of eminent domain might fall short of the required public use requirement: "There may be private transfers in which the risk of undetected impermissible favoritism of private parties is so acute that a presumption (rebuttable or otherwise) of invalidity is warranted under the Public Use Clause.”

The argument for a judicial hands-off - is not so strong as the Court's majority suggests, however. Justice O'Connor, who wrote the broadly worded Midkiff opinion for a unanimous Court in 1984, observed that the question of what is a public use is a judicial, not a legislative one. If economic development takings meet the public use requirement, there is no longer any distinction between private and public use of property, the effect of which is "to delete the words 'for public use' from the Takings Clause of the Fifth Amendment."

There was very little left of the public use clause - at least in federal courteven before the Kelo decision. While a growing handful of state decisions (and federal decisions applying state law on property) found economic revitalization public purposes invalid on constitutional grounds, an equal number of decisions agreed with the Connecticut Supreme Court that this was a valid public use. Clearly, this is also the view of hundreds of state and local revitalization and redevelopment agencies.

Whether one reads the Court's previous jurisprudence on public use broadly, as Justice Stevens does for the Court's majority, or more narrowly, as does the dissent, it is difficult to argue with the conclusions reached separately by Justice O'Connor: The public use clause is virtu- ally eliminated in federal court. What yellow light of caution the handful of recent cases signalled has now turned back to green, and the government may once more acquire private property by eminent domain on the slightest of public purpose pretexts unless such a use is inconceivable or involves an impossibility, the tests following Midkiff in 1984. In other words, it's now all about process, and process only.

There is no doubt that state and local governments will do much good in terms of public welfare and public benefits flowing from economic revitalization under such a relaxed standard, as they have often done in the past. And yet, the public use clause is more than simple policy; it is a bedrock principle contained in the Bill of Rights amendments to our federal constitution, designed not to further the goals and desires of the majority, but as a shield against majoritarian excesses at the expense of an otherwise defenseless minority-like the Kelos. Surely we could have found grounds to preserve that shield in federal court.

\title{
Debunking the Urban (Planning) Legends About Kelo
}

\author{
By John M. Baker
}

In Kelo, the petitioners asked the Supreme Court to do something it had never done before-strike "economic development" and "tax base enhancement" from the set of "conceivable public purposes." The property owners didn't seriously dispute that those were valid governmental objectives, or that condemning property can rationally further those goals. They wanted those objectives stricken from the list of "public purposes" so that property owners would win more often. It was an effort at revolutionary change that nearly succeeded.

Baker is a founding partner of Greene Espel P.L.L.P., a Minneapolis-based firm with a long-standing commitment to representation of public bodies and officlals. Contact him at Jbaker@greeneespel.com
If you rely upon headlines, AM radio, and op-ed pieces for your news about our highest court, you should be stunned to learn the following. More than 50 years ago in Berman v. Parker, the U.S. Supreme Court unanimously recognized that judges are particularly unsuited to tell public officials what is and is not a public purpose, and what use of eminent domain does or does not further such a purpose. In Berman, as in $K e l o$, the government took property that belonged to one private party, condemned it, and sold it to another private party. As in Kelo, the plaintiff's property in Berman was not blighted, but the surrounding area was. Yet the U.S. Constitution did not prohibit the government from deciding to purchase the property through eminent domain, so long as it paid its owner just compensation and provided the owner with due process.

Thirty years later, in another unanimous ruling in Hawaii Housing Authority v. Midkiff, the U.S. Supreme Court again held that the "public use" requirement does not prevent governments from con- 